\title{
FAKTOR PRODUKSI YANG BERPENGARUH TERHADAP BIAYA PRODUKSI SUSU PETERNAKAN SAPI PERAII DI KECAMATAN KARANGPLOSO, KABUPATEN MALANG, JAWA TIMUR
}

\author{
Budi Hartono ${ }^{1}$
}

\section{INTISARI}

Penelitian bertujuan untuk mengetahui faktor produksi yang berpengarula terhadap biaya produksi susu. Penelitian dilakukan di kecimattan Karangploso, kabupaten Malang, Jawa Timur pada bulan Desember 1995. Sampel diambil sebanyak 50 responden yang dilakukan secara acak. Data dianalisis secara diskriptif dan analisis regresi dengan fungsi produksi Cobb Douglas. Hasil analisis menunjukkan balıwa rata-rata produksi susu, biaya produksi susu dan nisbah ketergantungan masing-masing adalah 8,024 liter/ekor, Rp.507,78/liter dan 1,699. Hasil analisis tungsi produksi Cobb Douglas adalah $Y=7,9474$ $\mathrm{X}_{1}^{-0,0830} \mathrm{X}_{2}{ }^{0,79510} \mathrm{X}_{3}{ }^{-1,0250} \mathrm{X}_{4}{ }^{0,0113}$ dengan $\mathrm{Y}=$ Biayal produksi susu $\left(\mathrm{R}_{\mathrm{p}} / \mathrm{lt}\right), \mathrm{X}_{1}=$ Induk Laktasi (Unit ternak), $\mathrm{X}_{2}=$ Nisbah ketergantungan (Unit ternak), $\mathrm{X}_{3}=$ Produksi susu (litr/ckor), $X_{4}=$ Biaya pakan (Rp/ekor) dan koelisien determinasi sebesar 0,9968. Dari empat faktor produksi, hanya induk laktasi, produksi susu dan nisbah ketergantungan sangat berpengaruh terhadap biaya produksi susu. Dengan demikian, penambahan induk laktasi dan produksi susu akan mengurangi biaya produkși susu, sedangkan penambahan nisbah ketergantungan akan menambah biaya produksi susu.

(Kata Kunci: Biaya Produksi Susu, Nisbah Ketergantungan, Peternakan Sapi Perah.)

'Fakultas Peternakan UNIBRAW, Malang. 


\section{PRODUCTION FACTORS THAT INLLUENCE ON MILK PRODUCTION COST OF SMALL DAIRY FARMS IN KARANGPLOSO, MALANG EAST JAVA}

\section{ABSTRACT}

The objective of the research was to determine production factors affecting milk production cost. The study was conducted in Karangploso, Malang, East Java on December 1995. Fifty dairy farmers were chosen as respondents by random sampling. Data were analysed descriptively and by using Cobb Douglas production function. The results showed that milk production, milk production cost, and dependent ratio were $8.024 \mathrm{lt} / \mathrm{head}$, Rp.507.78/It and 1.699; respectively. The results obtained by Cobb Douglas production function was: $\mathrm{Y}=7.9474 \mathrm{X}_{1}{ }^{-0.0530} \mathrm{X}_{2}{ }^{.7950} \mathrm{X}_{3}{ }^{-1.0250} \mathrm{X}_{4}{ }^{.0113}$ where $\mathrm{Y}=$ milk production cost $(\mathrm{Rp} / \mathrm{It}), \mathrm{X}_{1}=$ lactating cows (Animal unit), $\mathrm{X}_{2}=$ dependent ratio (Animal unit), $\mathrm{X}_{3}=$ milk production (lt/head), $X_{4}=$ feed cost $(\mathrm{Rp} /$ head) and determination coefficient was .9968 . Number of lactating cows, number of milk production and dependent ratio significantly affected milk production cost. It was concluded that increasing number of lactating cows and milk production will decrease milk production cost, while increasing dependent ratio will increase milk production cost.

(Key Words: Milk Production Cost, Dependent Rațio, Small Dairy Farm.)

\section{Pendahuluan}

Usaha peternakan sapi peralı dewasa ini cukup mendapat perhatian dari pemerintah. Hal ini terbukti dengan diberikannya bantuan kredit sapi peralı kepada petani peternak sapi perah yang kebanyakan dikelola melalui koperasi. Dengan adanya introduksi sapi peral, diharapkan memiliki keuntungan yang multi dimensi, yang antara lain dapat mengoptimalkan jam kerja petani, mengatasi masalah pengangguran karena keterbatasan pemilikan lahan, dapat ditumpangsarikan dengan kegiatan pertanian lain untuk memanfaatkan limbalnya. Pengarulnya terhadap kegiatan ekonomi bukan pertanian, dapat memperluas kesempatan kerja bukan pertanian (off farm) di pedesaan karena meningkatnya permintaan akan kebutuhan barang dan jasa sebagai dampak dari peningkatan pendapatan dari hasil usaha sapi perah melalui keterkaitan konsumsi (Sutawi, 1995).

Kenyataan di lapangan menunjukkan bahwa rata-rata produksi susu per ekor sapi perah produktit yang dimiliki peternak sekarang ini (Tidak lebil dari 10 liter/huri/ekor) jauh lebih kecil jika dibandingkan dengan produksi susu sapi perah jenis Fries Holland (FH) yang dapat menghasilkan susu selama masa laktasi antara 4.500 sampai 5.500 liter. Walaupun dari taluun ke talsun produksi total meningkat, tetapi rati-rata produksi per ekor sapi produktif per hari menurun, hal ini menunjukkan bahwa telah terjadi suatu masalah dalam bidang produksi susu sapi perall (Riza, 1984).

Tujuan dari usaha peternakan sapi perah secara ekonomi yaitu usaha secara komersial untuk mendatangkan keuntungan dent

ekon

pada

fakto

sapi

dala!

lain

dan

usahe

mem

deng

munt

(Soel

dalan

yang

biaya

peral

menj:

prode

ternal

biaya

faktor

adalat

menc:

produ

prose

antara

maten

produ

merup

macar

fungsi

atau p

antara

input-

terseb:

produl

diguna

model

fungsi

salah s 
dengan menggunakan prinsip-prinsip ekonomi, sehingga peternak dapat bekerja pada keadaan optimal (Rasyaf, 1984). Faktorfaktor yang penting dalam usaha peternakan sapi perah terletak pada kemampuan peternak dalam menggabungkan beberapa faktor antara lain tatalaksana yang baik, besarnya usaha dan biaya produksi.

Seorang pengusaha dalam melakukan usaha peternakan selalu bertikir untuk memperoleh keuntungan yang lebilh besar dengan menekan biaya produksi sekecil mungkin. Hal ini dikenal dengan istilah biaya (Soekartawi, 1989), Komponen tambahan dalam biaya produksi susu adalah biaya pakan yang merupakan biaya terbesar dari seluruh biaya produksi pada usaha peternakan sapi perah (Morisson, 1957). Masalah lain yang menjadi kendala adalah ternak yang tidak produktif tentu akan menjadi beban bagi ternak yang produktif dalam meminimumkan biaya produksi.

Dalam bidang peternakan, umumnya faktor produksi yang paling berpengaruh adalal pakan, karena biaya pakan dapat mencapai $75 \%$ dari keseluruhan biaya produksi (Santosa, et al. 1979) Di dalam proses produksi terdapat hubungan kuantitatif antara input dan output, yang di dalam matematika dikenal dengan istilah fungsi produksi.

Dengan demikian sejumlah output merupakan suatu fungsi daripada bermacammacam input yang digunakan, sedangkan fungsi produksi sendiri adalah suatu fungsi atau persamaan yang menunjukkan hubungan antara tingkat output dan tingkat penggunaan input-input. Analisis dan estimasi hubungan tersebut dikenal sebagai analisi fungsi produksi. Bentuk fungsi produksi yang sering digunakan antara lain persamaan regresi model linier, model kuadratik dan model fungsi produksi Cobb Douglas.

Debertin (1986) menjelaskan bahwa salah satu bentuk fungsi produksi yang sering digunakan dalam analisis fungsi produksi pertanian adalah fungsi Cobb Douglas yang dapat dituliskan: $\mathrm{Y}=\mathrm{A} \quad \mathrm{X}^{\beta 1}{ }_{1} \mathrm{X}^{\beta 2}{ }_{2} \mathrm{X}^{\beta 3}{ }_{3}$ .......... $\mathrm{X}^{\beta_{a}}{ }_{n}$ dengan $\mathrm{Y}$ adalah produksi fisik, dan $X_{1}, X_{2}, X_{3} \ldots X_{n}$ adalah penggunaan faktor produksi serta $\beta^{1}, \beta^{2}, \beta^{3} \ldots \beta^{\mathrm{a}}$ adalah merupakan koefisien elastisitas produksi dari faktor-faktor produksi.

Penelitian ini mempunyai tujuan untuk mengetahui faktor produksi yang mempengaruhi biaya produksi susu. Diharapkan dengan penelitian ini dapat diatur penggunaan faktor produksi sehingga biaya produksi dapat ditekan serendah mungkin.

\section{Materi dan Metode}

Penelitian dengan menggunakan metode survei dengan materi penelitian adalah peternak sapi perah. Peternak ang dipilih sebagai peternak adalah peternak yang memiliki sapi perah laktasi minimal satu ekor, telah memelihara ternak sapi perah minimal satu tahun. Teknik pengumpulan data yaitu untuk data primer diperolel dengan wawancara langsung kepada peternak sapi perah yang berpedoman pada kuisioner yang telah dibuat.

Penelitian dilaksanakan di desa Bocek, kecamatan Karangploso, kabupaten Malang, yang dipilih secara sengaja dengan pertimbangan bahwa daeral tersebut merupakan daerah pengembangan usaha ternak sapi perah. Jumlah sampel yang digunakan dalam penelitian sebanyak 50 responden. Pengambilan sampel responden dilakukan secara acak (random) dari rumalı tangga yang mempunyai ternak sapi perah tersebut.

Dalam usaha mencapai tujuan penelitian yang diajukan akan dilakukan analisis diskriptif dan analisis regresi. 
Analisis diskriptif dimaksudkan untuk menggambarkan keadaan sapi perah di daerah peneditian, sedang analisis regresi dimaksudkan untuk menguji hubungan antara variabel tak bebas dengan variabel bebas yang dianalisis.

Fungsi produksi yang digunakan untuk menganalisis data tentang hubungan antara faktor-faktor produksi adalah fungsi produksi Cobb Douglas yang dapat dituliskan: $\mathrm{Y}=\mathrm{b}_{0} \mathrm{X}_{\mathrm{t}}^{\mathrm{b} 1} \mathrm{X}_{2}{ }^{\mathrm{b} 2} \mathrm{X}_{3}{ }^{\mathrm{b} 3} \mathrm{X}_{4}{ }^{\mathrm{b}}$

Keterangan:

$\mathrm{Y}=$ biaya produksi susu $(\mathrm{Rp} / \mathrm{lt})$,

$X_{1}=$ Induk laktasi (Unit ternak)

$\mathrm{X}_{2}=$ Nisbah ketergantungan (Unit ternak)

$\mathrm{X}_{3}=$ Produksi susu (liter/ekor)

$\mathrm{X}_{4}=$ Biaya pakan (Rp/responden)

$\mathrm{b}_{0}=$ Konstanta

$b_{1} \ldots b_{4}=$ Koefisien regresi yang sekaligus menunjukkan elastisitas.

\section{Hasil dan Pembahasan}

Dalam pembahasan berikut, masalah penguasaan sapi perah dimaksudkan untuk mengetahui komposisi perimbangan pemelihaaraan sapi perah yang berkaitan dengan kesinambungan usalia peternakan di daerah penelitian. Tabel 1 menunjukkan balıwa komposisi perimbangan pemilikan sapi perah meliputi prosentase peremajaan, imbangan sapi kering san laktasi, dan angka rasio produktif. Hasil perhitungan peremajaan diperoleh angka sebesar $14,41 \%$, imbangan sapi kering dan laktasi adalah $1: 2,36$ dan angka rasio produktif (Sedang laktasi) $59,32 \%$ (Tabel 1.). Hasil penelitian tersebut menunjukkan bahwa usaha peternakan sapi perah belum menampakkan adanya usaha yang berkesinambungan atau belum menampakkan adanya kontinuitas produksi, lal ini dapat terlihat data jumlalı ternak yang produktif sebesar $59,32 \%$ dan peremajaan hanya $14,41 \%$, serta imbangan sapi kering dengan sapi laktasi 1: 2,36 (Tabel 1). Angka tersebut masih relatif rendah karena idealnya peremajaan paling berkisar antara $20 \%$ sampai $25 \%$ jumlah ternak produktif minimal $60 \%$ dan imbangan sapi kering dan laktasi adalah 1:4 (Sudono, 1983). Pengaturan komposisi ini sangat penting karena perbandingan antara ternak yang produktif dan non produktif yang dipelihara dalam suatu usaha akan menentukan kelangsungan hidup usalat tersebut yang ditunjukkan dengan biaya produksi untuk ternak yang non produktif menjadi tanggungim sapi produktif, disamping untuk memperoleh kontinuitas produksi.

Nisbah ketergantungan (dependent ratio) rata-rata 1,69 (Tabel 2). Nilai nisbah ketergantungan diperoleh dari perbandingan antara jumlah seluruh ternak (Unit ternak) dengin jumlalı ternak yang produktif (sedang laktasi). Semakin besar nilai nisbah ketergantungan menandakan semakin banyak jumlah ternak non produktif yang dipelihara dalam suatu usaha tesebut selingga tanggungan yang dibebankan pada sapi produktif semakin besar.

Produksi susu di datrah penelitian rata-rata 8,024 liter per ekor per hari, sedangkan rata-rata produksi susu di Jawa Timur dilaporkan oleh Maharsi (1994) adalah 8,6 liter per ekor per hari. Demikian hasil pengamatan tidak jauh menyimpang. Rata-rata produksi susu per responden adalah 22,4 liter dengan skala usaba 4,72 Unit ternak (Tabel 2), produksi susu tersebut dapat dikatakan rendah karena jumlah sapi produktif tidak seimbang dengan jumlalı sapi non produktif.

Tabel 1 menunjukkan bahwa usaha ternak sapi perah dengan rata-rata skala usaha 4,72 UT, biaya produksi yang dikeluarkan sebanyak Rp,11.374,24 (Tabel 3). Dengan demikian rata-rata biaya produksi susu per liter adalah Rp.507,78 (Tabel 3). Tingginya biaya produksi susu
No. I

1. De

- In:

$-\operatorname{In}$

2. Dit

3. Pec

4. Per

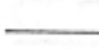

No.

1.

2.

per lite

besar

Tinggi

produk

untuk

produk

bahwa

59,32 \%

$40,68 \%$

sehing:

non pre

produk

susu m 
Tabel 1. Rata-rata penguasaan ternak sapi peralı

\begin{tabular}{lccc}
\hline \hline \multirow{2}{*}{ No. Komposisi } & \multicolumn{2}{c}{ Jumlah } & Persentase \\
\cline { 2 - 3 } & Unit & Ekor Ternak & \\
\hline 1. Dewasa & & & \\
- - Induk laktasi & 2,80 & 2,80 & 59,32 \\
- Induk kering & 1,22 & 1,22 & 25,85 \\
2. Darat & 0,56 & 0,28 & 5,93 \\
3. Pedet Betina & 1,60 & 0,40 & 8,48 \\
4. Pedet Jantan & 0,08 & 0,02 & 0,42 \\
\hline \multicolumn{1}{c}{ Jumlah } & 6,28 & 4,72 & 100,00 \\
\hline
\end{tabular}

Tabel 2. Rata-rata nisbah ketergantungan dan produksi susu

\begin{tabular}{llc}
\hline \hline No. Uraian & Rata-rata \\
\hline 1. & Nisbal Ketergantungan & 1,699 \\
2. & Produksi susu (liter) & \\
& - Per responden/hari & 22,400 \\
& - Per induk laktasi/hari & 8,024 \\
\hline
\end{tabular}

per liter disebabkan biaya untuk pakan terlalu besar yaitu $88,15 \%$ dari seluruh biaya total. Tingginya biaya pakan ini karena ternak yang produktif harus menanggung biaya pakan untuk yang non produktif dan rendahnya produksi susu. Dalam Tabel 1 disebutkan bahwa rata-rata ternak produktif hanya $59,32 \%$ dengan demikian sisanya yang $40,68 \%$ terdiri dari ternak yang non produktif sehingga biaya produksi untuk ternak yang non produktif dibebankan kepada ternak yang produktif, akibatnya biaya produksi per liter susu menjadi lebih tinggi.

Prinsip usaha ternak sapi perah adalah efisien dalam menggunakan faktor produksi sehingga dengan biaya produksi serendalı mungkin adalah merupakan tujuan utama, mengingat peternak tidak dapat menentukan harga produksi tetapi sebagai penerima harga produksi (price taker). Untuk itulah perlu dicari jalan keluarnya, faktor apa yang perlu diperhatikan sehingga biaya produksi dapat lebil ditekan.

Dalam penelitian berikut, terdapat empat variabel bebas yang digunakan untuk mengetahui indikator faktor produksi yang diperkirakan berpengaruh terhadap biaya produksi. Hasil analisis menunjukkan balıwa 
Tabel 3. Rata-rata biaya produksi

\begin{tabular}{llccc}
\hline \hline \multirow{2}{*}{ No. $\begin{array}{l}\text { Biaya } \\
\text { Produksi }\end{array}$} & \multicolumn{2}{c}{ Rata-rata } & \\
\cline { 3 - 4 } & & Rp/hari/responden & Rp/liter & $\begin{array}{l}\text { Pexsentase } \\
(\%)\end{array}$ \\
\hline 1. & Sewa tanah & 184,56 & 8,24 & 1,62 \\
2. & Penyusutan kandang & 153,81 & 6,87 & 1,35 \\
3. & Penyusutan alat & 137,45 & 6,14 & 1,21 \\
4. & Penyusutan ternak & 832,17 & 37,15 & 7,32 \\
5. & Biaya pakan & $10.026,74$ & 447,62 & 88,15 \\
6. & Biaya lainnya & 38,51 & 1,76 & 0,34 \\
\hline & Jumlah & $11.374,24$ & 100,00 & \\
\hline
\end{tabular}

Tabel 4. Koefisien regresi dengan fungsi produksi Cobb Douglas

\begin{tabular}{|c|c|c|c|c|}
\hline No. & Variabel & $\begin{array}{l}\text { Koefisien } \\
\text { Regresi }\end{array}$ & Nilai-t & $\begin{array}{l}\text { Pudubilits } \\
\text { Kescilahnn }\end{array}$ \\
\hline 1. & In $X_{1}$ (Induk laktasi) & -.0830 & $.7271^{* *}$ & .0000 \\
\hline 2. & $\ln X_{2}$ (Induk laktasi) & .7950 & $.9935^{* *}$ & .0000 \\
\hline 3. & $\ln X_{3}$ (Induk laktasi) & -1.0250 & $.9831^{* *}$ & .0000 \\
\hline 4. & $\ln \mathrm{X}_{4}$ (Induk laktasi) & .0113 & .0537 & .1111 \\
\hline 5. & Intercept (a) & 7.9474 & - & - \\
\hline 6. & Determinasi & .9968 & - & - \\
\hline
\end{tabular}

Keterangan: * berbeda sangat nyatu

koetisien determinasi sebesar 0,9968 (Tabel 4) berarti secara sangat meyakinkan bahwa keempat faktor produksi tersebut berpengaruh terhadap biaya produksi per liter susu.

Dalam Tabel 4 juga ditunjukkan bahwa faktor produksi jumlah induk laktasi (Unit ternak) dan jumlah produksi susu per hari per ekor mempunyai koefisien regresi negatif, berarti bahwa setiap penambahan kedua faktor produksi tersebut akan menurunkan biaya produksi per liter susu. Permasalahan dalam hal ini adalah balıwa kedua faktor produksi tersebut mempunyai elastisitas produksi negatif, berarti produksi berada pada daerah III atau daerah irrational. Apabila variabel tidak bebasnya adalah produksi susu maka penambahan jumlah sapi laktasi dan jumlah produksi susu merupakan tindakan yang irrational, tetapi berhubung variabel tidak bebasnya 
adalah biaya produksi susu maka dengan penambahan dua variabel bebasa tersebut merupakan tindakan yang logis karena akan mengurangi biaya produksi setiap liter susunya.

\section{Kajian terhadap probabilitas} kesalahau menunjukkan bahwa faktor produksi induk laktasi, nisbah ketergantungan dan produksi susu setiap ekornya berpengarulı samgat meyakinkan (Probabilitas 0,00) terladap biaya produksi setiap liternya. Untuk variabel bebas induk laktasi, apabila ditambah jumlalı ternaknya maka jelas akan mengurangi biaya produksi setiap liternya, demikian juga dengan produksi susu setiap ekornya. Pada variabel nisbah ketergantungan yang merupakan perbandingan antara jumbah scluruh ternak (UT) dengan jumlah ternak yang produktif (sedang laktasi) mempunyai koefisien regresi positif. Dengan demikian dapat dijelaskan bahwa dengan penambahan jumlah ternak yang tidak sedang laktasi (sapi kering, dara, jantan muda dan pedet) menandakan semakin banyak jumlah sapi tersebut yang dipelihara oleh responden akan menyebabkan tanggungan yang dibebankan pada sapi yang sedang laktasi semakin besar. Berarti semua biaya produksi menjadi tanggungan sapi yang sedang laktasi sehingga biaya produksi menjadi lebilh tinggi yang pada akhirnya biaya produksi setiap liter susu akan lebil tinggi.

\section{Kesimpulan}

Komposisi ternak yang dimiliki responden belum ideal sehingga belum menunjukkan kearah kesinambungan.

Biaya produksi susu per liter masih terlalu tinggi akibat masih banyaknya ternak non produkif.
Nisbah ketergantungan berpengaruh positif terhadap biaya produksi susu.

Produksi susu setiap ekor dan jumlah ternak laktasi berpengaruh negatif terhadap biaya produksi susu.

\section{Daftar Pustaka}

Debertia, D.L. 1986. Agricultural Production Eeonomics. Third Avenue. Macmillan Publishing Compuny. New York.

Maharsi. A.D. 1994. Upaya Peningkatan Pendapatan Pelernakan Sapi Perah di Jawa Timur. Makaluhdisampaikandalam "Diskusi Panel" pada tanggal 29 Januari 1994 di Universitas Brawijaya Mulang.

Morisson, F.B. 1957. Feed und Feeding. The Morisson Publishing Company. Twenty Second Editions. Itlutca. New York.

Rusyaf M. 1984. Programusi Limear untuk Industri Russum Terauk. Penerbit Kunisius Yogyukurta.

Rizu, S.G. 1984. Efisiensi Ekonomis Usahatani Peternukun Supi Perah Rukyat di Kelurahun Kebon Pedes, Kotamadya Bogor. Karya Ilminh Sarjuna Pertanian, Fakultas Pertanian IPB Bogor.

Santosa, Sorta S, C.H. Sirait dan R.R.L. Tobing. 1975. Perbandingan Biaya Produksi dan Pendapatan peternakan Sapi Perah di dacrah Bogor, Bandung dun Jukurta. Bulletin No. 13. Lembaga Penelitiun Peternakun Bogor.

Sockurtawi. 1989. Prinsip-Priusip Dusur Ekonomi Pertuniun. Teori dau Aplikasi. Rajawali Press Jakarta.

Sudono, A. 1983. Produksi Sapi Perah. Jurusan Produksi Ternak. Fakulus Peternakan. lnstitut Pertenian Bogor. Bogor.

Sutawi. 1995. Liberalisasi Perdagangan dan Nasib Peternak Sapi Perah. Majalah Ruminansia. No. 3. Tahun IX tanggal 20 Januari - 20 Februari 1995. 